\title{
PENGARUH SUCTION TERHADAP KADAR SATURASI OKSIGEN PADA PASIEN KOMA DI RUANG ICU RSUD Dr. MOEWARDI SURAKARTA TAHUN 2015
}

\author{
Afif Muhamad Nizar, Dwi Susi Haryati \\ Kementerian Kesehatan Politeknik Kesehatan Surakarta Jurusan Keperawatan
}

\begin{abstract}
Saturation Of Oxygen, Suction, Coma Patients. Decreas consciousness and coma is very deep response. Comatose patients often experience problems mainly due to accumulation of secretions that coma patients decreased cough reflex. So that the patient needs to be done to free the airway suctioning of secretions. A phenomenon that occurs in the ICU Hospital Dr. Moewardi almost comatose patients conducted periodically suction approximately every 2 hours. The purpose of this study was to determine the effect of suction on oxygen saturation in patients with coma in the ICU Hospital Dr. Moewardi Surakarta 2015. This type of research is quasy experimental research design is a one-group pretest-posttest design and analysis using paired samples T-test.Based on the results of the Shapiro-Wilk normality test can be concluded that the data tedistribusi normal. So using a paired samples T test with significance value $(p)$ was 0.000 , which is the value of $p<0.05$. This means that there is an average difference of oxygen saturation value before the suction action after the suction action. Oxygen saturation difference is -1.79 , meaning that oxygen saturation values prior to suction smaller than the value of the oxygen saturation after the suction.
\end{abstract}

Keywords: Saturation Of Oxygen, Suction, Coma Patients

Abstrak : Saturasi Oksigen, Suction, Pasien Koma. Koma adalah penuruanan kesadaran dan respon yang sangat dalam. Pasien koma sering mengalami permasalahan terutama penumpukan sekret yang dikarenakan pasien koma mengalami penurunan reflek batuk. Sehingga pasien perlu dilakukan suction untuk membebaskan jalan napas dari sekret. Fenomena yang terjadi di ruang ICU RSUD Dr. Moewardi hampir pasien koma dilakukan suction berkala kurang lebih setiap 2 jam.Tujuan dari penelitian ini adalah untuk mengetahui pengaruh suction terhadap saturasi oksigen pada pasien koma di ruang ICU RSUD Dr. Moewardi Surakarta tahun 2015. Jenis penelitian ini adalah quasy eksperimen dengan rancangan penelitian adalah one-group pretest-postest design dan menggunakan analisa paired samples $T$ test.Berdasarkan hasil uji normalitas Shapiro-Wilk dapat disimpulkan bahwa data terdistribusi normal. Sehingga menggunakan uji paired samples $T$ test dengan nilai signifikasi (p) adalah 0.000, dimana nilai tersebut $\mathrm{p}<0.05$. Artinya ada beda rata rata nilai saturasi oksigen sebelum tindakan suction dengan setelah tindakan suction. Selisih saturasi oksigen adalah -1.79 , artinya nilai saturasi oksigen sebelum dilakukan suction lebih kecil dibanding nilai saturasi oksigen setelah dilakukan suction.

Kata Kunci: Saturasi Oksigen, Suction, Pasien Koma 


\section{PENDAHULUAN}

Koma merupakan keadaan penurunan kesadaran dan respons dalam bentuk yang berat, kondisi seperti tidur yang dalam dimana pasien tidak mampu bangun dari tidurnya (Sudoyo, et al. 2010). Umumnya seseorang akan mengalami koma selama beberapa minggu. Tepati, ada pula yang mengalami koma hingga waktu berbulan-bulan. Jika hal itu terjadi, kemungkinan untuk meninggal dunia lebih besar.Penyakit yang menyebabkan penurunan kesadaran (koma) antara lain adalah stroke, kanker, penyakit jantung, DM dan lain-lain. Data WHO (2012) menunjukan bahwa kematian akibat penyakit pembuluh darah lebih banyak dari pada penyakit lainnya yaitu sekitar 15 juta tiap tahun atau sekitar $30 \%$ dari kematian total per tahun dan sekitar 6,2 juta diantaranya disebabkan oleh stroke. Sedangkan penelitian yang dilakukan oleh Fredi di RSUP Dr. Sardjito Yogjakarta menjelaskan dari 88 pasien stroke sebanyak $41,7 \%$ mengalami penurunan kesadaran. Selain itu pasien dengan penurunan kesadaran sering mengalami permasalahan pada saluran pernafasan yaitu produksi sekret yang berlebih dimana dapat menghambat aliran udara dari hidung masuk ke paru-paru.

Sekret merupakan bahan yang dikeluarkan dari paru, bronchus, dan trachea melalui mulut. Biasanya juga disebut dengan expectoratorian. Orang dewasa normal bisa memproduksi mukus (sekret kelenjar) sejumlah $100 \mathrm{ml}$ dalam saluran napas setiap hari.Mukus ini digiring ke faring dengan mekanisme pembersihan silia dari epitel yang melapisi saluran pernapasan.Keadaan abnormal penumpukan sekret yang berlebihan pada pasien koma dikarenakan tidak mempunyai reflek batuk yang efektif untuk mengeluarkan sekret. Pasien koma harus dilakukan suction untuk mengeluarkan sekret supaya tidak terjadi penumpukan sekret dan penurunan saturasi oksigen. Oleh karena itu perlu dilakukan penelitian mengenai pengaruh suction terhadap saturasi oksigen.

Suction merupakan suatu cara untuk mengeluarkan sekret dari saluran nafas dengan menggunakan kateter yang dimasukkan melalui hidung atau rongga mulut kedalam pharyng atau trachea. Penghisapan lendir digunakan bila pasien tidak mampu membersihkan sekret dengan mengeluarkan atau menelan. Tindakan penghisapan lendir perlu dilakukan pada pasien yang mengalami penurunan kesadaran karena kurang responsif atau yang memerlukan pembuangan sekret oral. Dengan dilakukan tindakan suction diharapkan saturasi oksigen pasien dalam batas normal (>95\%).

Saturasi oksigen merupakan presentasi hemoglobin terhadap oksigen dalam arteri. Penurunan nilai dari saturasi oksigen dapat diartikan adanya gangguan pada sistem pernapasan seperti hipoksia dan obstrusi saluran napas. Keadaan yang lebih buruk dari penurunan saturasi oksigen adalah apabila lebih dari 4 menit pasien tidak mendapatkan oksigen maka akan berakibat pada kerusakan otak yang tidak dapat diperbaiki dan biasanya pasien akan meninggal. Penelitian yang dilakukan oleh Welri (2012) di RS Paru Dr. Ario Wirawan Salatiga menyimpulkan hasil penelitian bahwa terdapat pengaruh saturasi oksigen terhadap penempetan posisi yaitu posisi fowler terjadi kenaikan 4,99\%, posisi semi fowler terjadi kenaikan 2,87 dan posisi terlentang terjadi kenaikan $6,25 \%$. 
Hasil wawancara dengan salah satu perawat ICU RSUD Dr. Moewardi pada tanggal 3 Januari 2015 mengatakan jumlah pasien koma pada tahun 2013 yang dirawat di ICU sekitar 500-650 pasien dan setiap hari pasien koma yang dirawat sekitar 5-6 (30-40\%) pasien dari 16 bed yang tersedia. Sedangkan pada tahun 2014 terjadi peningkatan pasien koma yang dirawat di ICU yaitu sekitar 700-800 pasien dan setiap hari pasien koma yang dirawat sekitar 6-8 (40\%-50\%) dari 16 bed yang tersedia. Peningkatan pasien koma didominasi oleh pasien trauma kepala akibat kecelakan. Hasil observasi langsung di ruang ICU RSUD Dr. Moewardi pada tanggal 8 Desember 2014 selama satu minggu didapatkan pasien dalam kondisi koma sebanyak 17 pasien dan setiap pasien koma dilakukan suction berkala kurang lebih setiap 2 jam dengan tujuan mengeluarkan sekret supaya jalan napas efektif dan suplai oksigen ke jaringan efektif.

Dari uraian di atas dianggap perlu dilakukan penelitian mengenai pengaruh suction terhadap kadar saturasi oksigen pada pasien koma di ruang ICU RSUD Dr. Moewardi Surakarta tahun 2015.

\section{METODE PENELITIAN}

Penelitian ini merupakan penelitian quasy eksperimen dengan rancangan penelitian One-Group PretestPosttes design. Sugiyono, (2008) menjelaskan quasy eksperimental adalah suatu bentuk penelitian yang dilakukan untuk mengetahui akibat yang ditimbulkan dari suatu perlakuan dengan bertujuan untuk menilai pengaruh suatu perlakuan. One-Group Pretest-Posttes yaitu design yang dilakukan observasi sebanyak 2 kali sebelum dan setelah eksperimen (Sugiyono, 2008).
Penelitian ini telah dilakukan di ruang ICU RSUD Dr. Moewardi pada tanggal 9 Maret sampai 7 Mei 2015. Populasi penelitian ini adalah semua pasien yang mengalami koma dengan jumlah sampel akhir adalah 40 responden.

Kriteria inklusi pada penelitian ini adalah: pasien koma yang dirawat di ruang ICU RSUD Dr. Moewardi, pasien koma yang dirawat di ruang ICU RSUD Dr. Moewardi 1 jam perawatan di hari pertama, pasien koma yang berusia $>12$ tahun dan pasien koma yang disetujui oleh penanggung jawab untuk dijadikan responden. Kriteria eksklusi pada penelitian ini adalah : Pasien koma yang pernah mendapatkan tindakan suction di ruang ICU RSUD Dr. Moewardi, pasien koma yang mendapatkena terapi nebulizer di ruang ICU RSUD Dr. Moewardi, pasien koma dengan Edema paru di ruang ICU RSUD Dr. Moewardi.

Penelitian ini terdiri dari dua variabel yaitu variabel bebas dan variabel terikat. Variabel bebas (Independen) pada penelitian ini adalah suction dengan alat ukur standar operasional prosedur. Variabel terikat (Dependen) pada penelitian ini adalah perubahan kadar saturasi oksigen dengan alat ukur oksimetri dan skala interval.

Bentuk instrumen dalam penelitian ini adalah lembar observasi digunakan selama proses pengambilan data untuk mencatat hasil observasi pada responden yang diukur nilai saturasi oksigen sebelum dan sesudah dilakukan suction, kemudian dicatat pada lembar observasi.

Tahapan-tahapan yang akan dilakukan pada pengolahan data adalah : Editing (Pemeriksaan Data), peneliti meneliti kembali kelengkapan pengisian data pada lembar observasi yang digunakan. Coding, (memberikan kode) 
peneliti memberikan kode pada jenis kelamin dan usia responden. Pada data jenis kelamin : angka 1 untuk laki-laki dan angka 2 untuk perempuan. Sedangkan untuk usia : kelompok usia 21-30 tahun diberikan kode angka 1, kelompok usia 31-40 tahun diberikan kode angka 2, kelompok usia 41-50 tahun diberikan kode angka 3, kelompok usia 51-60 tahun diberikan kode angka 4, kelompok usia $>60$ tahun diberikan kode angka 5 . Scoring (Penilaian),peneliti memberikan penilaian skor 1-2 pada data jenis kelamin, 1-5 untuk data usia dan \% untuk kadar saturasi oksigen. Tabulating (Mengolah Data), peneliti memasukkan data hasil penelitian berdasarkan klasifikasi ke dalam tabel sesuai dengan data yang didapat dari responden yaitu data jenis kelamin, usia dan kadar saturasi oksigen baik sebelum maupun setelah dilakukan suction.

Penelitian ini menggunakan dua analisis data yaitu analisis univariat dan bivariat. Analisa univariat dilakukan dengan tujuan untuk mendeskripsikan variabel dengan cara membuat tabel distribusi frekuensi dari variabel yang diteliti. Analisa bivariat digunakan untuk mengetahui pengaruh antara suction sebagai variabel independen terhadap saturasi oksigen sebagai variabel dependen. Kemudian dilakukan uji normalitas Shapiro-Wilk karena jumlah sampel 40 responden dan hasil uji normalitas menunjukan data terdistribusi normal. Maka uji statistik yang digunakan adalah parametrik paired $t$ test.

Tahap pelaksanaan memilih responden sesuai dengan kriteria inklusi sampel dan melakukan inform confirm terhadap penanggung jawab pasien. Setelah itu peneliti mengukur saturasi oksigen sebelum tindakan suction dan mengukur kembali saturasi oksigen setelah tindakan suction pada kurun waktu 1 jam pertama responden mendapatkan perawatan dihari pertama. Kemudian tindakan suction dilakukan sebanyak 4 kali dalam rentang waktu 2 jam. Data pre saturasi oksigen diambil dari tindakan suction yang pertama dan data post diambil dari tindakan suction yang keempat selang waktu 10 detik.

\section{HASIL PENELITIAN} Tabel 1

Analisa Diskriptif Karakteristik

Responden Berdasarkan Jenis Kelamin dan Umur

\begin{tabular}{llcc}
\hline \multicolumn{2}{c}{ Karakteristik } & N & $\begin{array}{c}\text { Presentase } \\
(\%)\end{array}$ \\
\hline Jenis & Laki-laki & 26 & 65.0 \\
kelamin & Perempuan & 14 & 35.0 \\
\hline \multirow{4}{*}{ Usia } & 21-30 tahun & 2 & 5.0 \\
& 31-40 tahun & 4 & 10.0 \\
& 41-50 tahun & 7 & 17.5 \\
& 51-60 tahun & 10 & 25.0 \\
& $>61$ tahun & 17 & 42.5 \\
\hline
\end{tabular}

Tabel 2

Analisa Saturasi Oksigen Sebelum Tindakan Suction

\begin{tabular}{cccccc}
\hline $\mathrm{N}$ & \multirow{2}{*}{ Mean } & Median & $\mathrm{SD}$ & $\begin{array}{c}\text { Minimum/ } \\
\text { Maximum }\end{array}$ & $\begin{array}{c}95 \% \\
\mathrm{CI}\end{array}$ \\
\hline 40 & 89.86 & 89.00 & 6.06 & $78 / 100$ & 87.94 \\
& & & & & - \\
& & & & & 91.81 \\
\hline
\end{tabular}

Tabel 3

Analisa Saturasi Oksigen Setelah Tindakan Suction

\begin{tabular}{cccccc}
\hline N & Mean & Median & SD & $\begin{array}{c}\text { Minim } \\
\text { um/ } \\
\text { Maxi } \\
\text { mum }\end{array}$ & $95 \%$ CI \\
\hline 40 & 91.65 & 91.50 & 5.26 & $80 / 10$ & $89.97-$ \\
& & & 0 & 93.33 \\
\hline
\end{tabular}


Tabel 4

Hasil Uji Normalitas Shapiro-Wilk

\begin{tabular}{ccccc}
\hline & N & Mean & SD & $\begin{array}{c}\text { p- } \\
\text { value }\end{array}$ \\
\hline Pretest & 40 & 89.86 & 6.06 & 0.240 \\
\hline Posttest & 40 & 91.65 & 5.26 & 0.116 \\
\hline
\end{tabular}

Tabel 5

Analisa Perubahan Saturasi Oksigen Sebelum Dan Setelah Dilakukan

\begin{tabular}{cccccc}
\multicolumn{7}{c}{ Suction } \\
\hline $\mathrm{N}$ & Mean & SD & SE & T & $\begin{array}{c}\text { p- } \\
\text { value }\end{array}$ \\
\hline 40 & -1.79 & 2.948 & 0.466 & -3.808 & 0.000 \\
\hline
\end{tabular}

\section{PEMBAHASAN}

Penelitian dilakukan di ruang ICU

RSUD Dr. Moewardi dengan jumlah sampel 40 responden. Sampel terbanyak berdasarkan jenis kelamin adalah laki-laki sedangan sampel terbanyak berdasarkan usia adalah usia diatas 60 tahun.Hasil penelitian tersebut menunjukan bahwa jenis kelamain laki-laki lebih banyak dari pada perempuan, hal ini dikarenakan jumlah responden yang sesuai dengan kriteria inklusi pada saat penelitian didominasi oleh laki-laki. Selain itu peneliti juga belum menemukan teori yang menjelaskan bahwa jenis kelamin mempengaruhi terjadinya keadaan koma. Sedangkan hasil penelitian dari Purwoko (2009) dengan judul "Pengaruh Terapi Musik Terhadap Tingkat Kesadaran berdasarkan Nilai Glasgow Coma Scale (GCS) Pada Pasien Koma”, menjelaskan jumlah responden dengan keadaan koma didominasi oleh perempuan dengan jumlah 15 responden $(75 \%)$. Oleh karena itu, dalam penelitian ini tidak membedakan jenis kelamin untuk dijadikan responden. Sehingga apabila terdapat responden yang sesuai dengan kriteria inklusi baik laki-laki ataupun perempuan tetap memdapatkan tindakan suction sesuai dengan standar operasional prosedur.

Hasil penelitian ini menyebutkan bahwa usia di atas 61 tahun adalah terbanyak dikarenakan pasien koma yang sesuai dengan kriteria inklusi pada saat penelitian didominasi usia tua. Selain itu diagnosa dari responden penelitian cenderung lebih banyak dengan diagnosa medis Diabetes Mellitus, Chronic Kidney Disease atau gagal ginjal dan Stroke baik strokeiskemi atau haemoraghe. Dimana penyakit tersebut merupakan faktor resiko ketika seseorang memasuki usia tua. Penelitian ini hampir sama dengan hasil penelitian dari Asrin, Mardiyono dan Saryono (2007) bahwa dalam penelitiannya mengenai pengaruh terapi musik terhadap peningkatan kesadaran menunjukan responden dengan usia >60 tahun mempunyai prevelensi terbanyak sebesar 55\% atau 11 responden. Darmojo (1999) juga menjelaskan bahwa usia lanjut atau diatas 60 tahun secara berlahan-lahan kehilangan kemampuan tubuh untuk mengganti sel yang rusak dan mempertahankan struktur dan fungsi normalnya sehingga tidak dapat bertahan terhadap rangsangan (misalnya penyakit) dan tidak mampu memperbaiki kerusakan yang di derita.

Meskipun demikian, peneliti tidak membedakan responden berdasarkan usia dalam melakukan tindakan suction. Brunner dan Suddart (2002) menjelaskan pasien tidak sadar prioritas tindakan medis menggunakan urutan ABCDE (Airway, Breathing, Circulation, Disability dan Exposure). Oleh karena itu peneliti melakukan tindakan suction sesuai standar operational prosedur terhadap responden dan tidak membedakan usia.

Nilai rata-rata saturasi oksigen sebelum tindakan suction pada penelitian 
ini menunjukan lebih kecil dari pada nilai saturasi oksigen setelah suction. Hal tersebut dikarenakan adanya sumbatan jalan napas yang menghambat oksigen masuk kedalam paru-paru. Oleh Karena itu dilakukannya suction sesuai dengan standar operasional prosedur supaya jalan napas bersih sehingga oksigen efektif masuk ke dalam paru-paru sehingga saturasi oksigen naik.

Nilai rata-rata saturasi oksigen setelah tindakan suction pada penelitian ini menunjukan lebih besar dari pada nilai saturasi oksigen sebelum suction. Hal tersebut dikarenakan sumbatan jalan napas yang menghambat oksigen masuk kedalam paru-paru sudah dikeluarkan dengan tindakan suction. Sehingga peneliti melakukan tindakan suction sesuai dengan standar operasional prosedur untuk membebaskan sumbatan jalan napas terutama sekret.

Sebelum melakukan uji hipotesis peneliti melakukan uji normalitas. Menurut Notoadmojo (2010) jika jumlah sampel <50 maka menggunakan uji normalitas Shapiro-Wilk sedangkan jika jumlah sampel $>50$ maka menggunakan uji normalitas Shapiro-Wilk. Karena jumlah sampel dari penelitian ini adalah 40 responden maka menggunakan uji normalitas Shapiro-wilk. Jumlah hasil uji normalitas pretest adalah 0.240 , sehingga signifikasi ( $p>0.05$ ) dengan demikian Ho diterima yang artinya data berdistribusi normal dan hasil uji normalitas postest adalah 0.116, sehingga signifikasi ( $>0.05)$ dengan demikian Ho diterima yang artinya data berdistribusi normal. Selain dari uji statistik bahwa data terdistribusi normal dapat dibuktikan dari bentuk histogram dan grafik P-Plot baik pretest maupun posttest. Dimana histogram berbentuk lonceng yang artinya data terdistribusi normal dan P-Plot terdapat titik-titik di sepanjang garis linier yang artinya data terdistribusi normal. Karena dari kedua data baik pretest maupun postest terdistribusi normal maja uji hipotesis yang digunakan adalah paired samples t test.

Hasil uji paired samples $t$ test nilai signifikasi (p) adalah 0.00 , dimana nilai tersebut $\mathrm{p}<0.05$. Artinya ada beda ratarata nilai saturasi oksigen sebelum tindakan suction dengan setelah tindakan suction. Selisih rata-rata nilai saturasi oksigen sebelum dan setelah tindakan suction adalah $-1.79 \%$ yang artinya ratarata nilai saturasi oksigen sebelum dilakukan suction lebih kecil dibanding nilai saturasi oksigen sesudah dilakukan suction. Hal ini sesuai dengan penelitian yang dilakukan oleh Mulyadi, Kitong dan Malara (2011) dalam penelitiannya yang berjudul "Pengaruh Tindakan Penghisapan Lendir Endotrakeal Tube (Ett) Terhadap Kadar Saturasi Oksigen Pada Pasien Yang Dirawat Di Ruang Icu Rsup Prof. Dr. R. D. Kandou Manado”, menjelaskan bahwa terdapat perbedaan kadar saturasi oksigen sebelum dan sesudah diberikan tindakan penghisapan lender (suction).

Hasil penelitian ini menunjukan adanya peningkatan dari kadar saturasi oksigen setelah dilakukan suction. Hal tersebut dikarenakan terbebasnya jalan napas terhadap akumulasi sekret menjadikan perpindahan oksigen dari atmosfer ke dalam paru-paru menjadi efektif. Oleh karena itu peneliti melakukan tindakan suction terhadap responden yang sesuai dengan kriteria inklusi berdasarkan standar operasinal prosedur.

Selisih dari saturasi oksigen dalam penelitian ini bernilai -1.79 . Hal tersebut 
berbeda dengan selisih dari hasil penelitian yang dilakukan oleh Kitong, Malara dan Mulyadi (2011) yang bernilai $5,174 \%$. Karena penelitian ini dalam pengambilan data post dilakukan setelah 10 detik tindakan suction yang bertujuan untuk memberikan kompensasi terhadap paru-paru untuk melakukan pertukaran gas dan jantung untuk memompa darah. Hal tersebut sesuai dengan teori dariAsmadi (2009)bahwa dalam membaca hasil saturasi oksigen tidak dilakukan seketika setelah dilakukan suction tetapi selang waktu 10-15 detik supaya pasien mendapatkan kesempatan bernapas dan oksigen sudah terdistribusi keseluruh tubuh. Sehingga semua data post dalam penelitian ini diambil setelah dilakukan suction selang waktu 10 detik.

Hasil rata-rata kadar saturasi oksigen setelah dilakukan suction untuk 2 jam pertama adalah $91.23 \%, 2$ jam kedua adalah $91.32 \%, 2$ jam ketiga adalah $91.43 \%$ dan 4 jam keempat adalah 91.65\%. Dari setiap 2 jam rentang tindakan suction menunjukan adanya peningkatan kadar saturasi oksigen. Hal tersebut menunjukan semakin bersihnya jalan napas akan meningkatkan keefektifan pertukaran gas. Sehingga semua responden dalam penelitian ini mendapatkan tindakan suction sesuai standar operasional prosedur setiap 2 jam.

Dalam penelitian ini tindakan suction dilakukan setiap rentang 2 jam. Karena untuk meminimal terjadinya faktor pengganggu dari tindakan nebulizer. Dimana nebulizer adalah alat yang digunakan untuk menguapkan obat seperti pelancar dahak dan asma. Sehingga responden yang mendapatkan terapi nebulizer termasuk kriteria eksklusi sampel.

\section{KESIMPULAN DAN SARAN}

Berdasarkan hasil penelitian terhadap 40 responden di ruang ICU RSUD Dr. Moewardi dapat disimpulkan bahwa:Karakteristik responden terbanyak berdasarkan jenis kelamin yaitu laki-laki sebesar 26 responden (65\%), sedangkan responden terbanyak berdasarkan usia adalah usia > 61 tahun sebesar 17 responden $(42,5 \%)$.Nilai saturai oksigen sebelum dilakukan tindakan suction meliputi nilai mean adalah $89.86 \%$, nilai median adalah $89.00 \%$, nilai standar deviation adalah $6.06 \%$, nilai minimum adalah $78 \%$, nilai maximum $100 \%$ dan nilai confidence intervaladalah $87.94 \%$ $91.81 \%$. Nilai saturasi oksigen setelah dilakukan tindakan suction meliputi nilai mean adalah $91.65 \%$, nilai median adalah $91.50 \%$, nilai standar deviation adalah $5.26 \%$, nilai minimum adalah $80 \%$, nilai maximum $100 \%$ dan nilai confidence interval adalah $89.97 \%-93.33 \%$.Ada pengaruh tindakan suction terhadap nilai saturasi oksigen ( $\mathrm{p}<0.005)$, sehingga $\mathrm{Ha}$ diterima. Dimana selisih rata-rata saturasi oksien adalah -1.79 (mean pretest $<$ mean posttest).

Berdasarkan hasil penelitian yang telah dilakukan, peneliti memberikan saran sebagai berikut: Bagi sesama profesi, penelitian ini diharapkan dapat menambah wawasan keilmuan terutama dalam pemberian tindakan keperawatan kritis untuk meningkatkan saturasi oksigen khususnya pada pasien koma. Bagi peneliti lanjut, diharapkan dapat melakukan penelitian yang lebih komplek baik dalam variabel, jumlah sampel, menentukan kriteria sampel maupun metode penelitian yang digunakan.Bagi rumah sakit penelitian ini dapat meningkatkan mutu pelayanan dalam 
meningkatkan saturasi oksigen khususnya pada pasien koma.

\section{DAFTAR RUJUKAN}

Arikunto, S. (2012). Prosedur Penelitian Suatu Pendekatan Praktek. Jakarta: Rineka Cipta.

Asmadi. (2009). Teknik Prosedural Keperawatan Konsep dan Aplikasi Kebutuhan Dasar Klien. Jakarta: Salemba Medika.

Corwin, E.J. (2001). Handbook of pathophysiology. Alih bahasa: Pendit, B.U. Jakarta: EGC; (Buku asli diterbitkan tahun 1996)

Darmojo,R.B. (1999). Buku Ajar Geriatri (Ilmu Kesehatan Usia Lanjut) Edisi 2. FKUI.

Dewanto, G., Suwono, W.J., Riyanto, B., \& Turana. (2009). Diagnosis \& Tata laksana Penyakit Saraf. Jakarta: EGC.

Harsono. (1996). Buku Ajar Neurologi Klinis. Yokyakarta: Gajah Mada University Press.

Hidayat, A.A.A. (2007). Pengantar Dasar Konsep Keperawatan. Jakarta: Salemba Medika.

Kozier, B\& Erb, G. (2009). Buku Ajar Praktik Keperawatan Klinis. Edisi 5. Jakarta : EGC.

Notoadmojo, S. (2010). Metode Penelitian Kesehatan. Jakarta : PT. Rineka Cipta

Nursalam. (2008). Konsep dan Penerapan Metode Penelitian Ilmu Keperawatan, Edisi 2. Jakarta : Salemba Medika.

Mansjoer, A. (2000). Kapita Selekta Kedokteran. Jakarta: Media Aesculapius.
Padmosantjojo. (2000). Keperawatan Bedah Saraf. Jakarta: Bagian Bedah Saraf FKUI.

Philip, J \& Beverlay, E. (2010). Pemantauan Pasien Kritis. Jakarta: Erlangga.

Price, S.A. \& Wilson, L.M. (1994). Pathophysiology: Clinical concept of disease processes. $4^{\text {th }}$ Edition. Alih bahasa : Anugerah, P. Jakarta: EGC; (Buku asli diterbitkan tahun 1992).

Smeltzer, S.C. \& Bare, B.G. (2002). Brunner and Suddarth's textbook of medical - surgical nursing. $8^{\text {th }}$ Edition. Alih bahasa: Waluyo, A. Jakarta: EGC; (Buku asli diterbitkan tahun 1996).

Sudoyo, A.W, Setyohadi, B, Alwi I, Setiati S. (2007). Buku Ajar Ilmu Penyaikit Dalam. Jilid V. FKUI.

Sugiyono. (2008). Statistik Untuk Penelitian. Bandung: Alfabeta.

Sulistyowati, E.C., \& Handayani, S. 2012. Pengaruh Cognitive Behavioural Therapy (CBT) terhadap Perubahan Kecemasan, Mekanisme Koping, Harga Diri pada pasien Gangguan Jiwa dengan Skizofrenia di RSJD Surakarta. Surakarta.

Suwono \& Riyanto. (2009). Penatalaksanaan Pasien Gawat Darurat. Jakarta: EGC

Tamsuri, B. K. (2008). Seri Asuhan Keperawatan Klien Gangguan Pernapasan. Jakarta : EGC.

Timby, B.K. (2009). Fundamental Nursing Skills and Concepts. Philadelphia: Lippincot William \& Wilkins. 